Indonesian Journal of Biotechnology, December, 2013

Vol. 18, No. 2, pp.133-143

\title{
The Development of Pathogenicity of Avian Influenza Virus Isolated from Indonesia
}

\author{
Michael Haryadi Wibowo ${ }^{1 *}$, Eko Agus Srihanto ${ }^{2}$, Khrisdiana Putri ${ }^{3}$, \\ Widya Asmara ${ }^{4}$, and Charles Rangga Tabbu ${ }^{5}$
}

\author{
${ }^{1,4}$ Department of Microbiology, Faculty of Veterinary Medicine, Universitas Gadjah Mada \\ ${ }^{2}$ Diseases Investigation Center, Jl. Untung Suropati 2, Bandar Lampung. \\ ${ }^{3}$ Department of Veterinary Public Health, Faculty of Veterinary Medicine, Universitas Gadjah Mada \\ ${ }^{5}$ Department of Pathology, Faculty of Veterinary Medicine, Universitas Gadjah Mada
}

\begin{abstract}
Highly pathogenic avian influenza outbreak in Indonesia has been reported in various poultry due to H5N1 subtype. The presence of multiple basic amino acids within the cleavage site of HA glycoprotein has been identified to be associated with the pathogenicity of avian influenza virus. The study was retrospective study which was designed to characterize the cleavage site and fusion site region of haemagglutinin gene of AIV isolated from various poultry in 2003 to 2013. Isolation, Identification and propagation were carried out to collect viral stock. For virus detection, reverse transcriptase PCR (RT-PCR) method on H5 and N1 gene fragment was performed. All of RT-PCR HA gene positive products were sequenced for further nucleotide analysis and to determine the nucleotide composition at the targeted fragment. The results are all AIV isolates were identified as H5N1 subtype. The sequence analyses revealed some motives of basic amino acid motive that were classified as highly pathogenic avian influenza virus. Further analyses on fusion domain of all AIV isolated during the period 2003 to 2013 showed conserved amino acid.
\end{abstract}

Keywords: avian influenza, haemagglutinin, cleavage site, basic amino acid, fusion site

\section{Introduction}

Highly pathogenic avian influenza (AI) in Indonesia has been reported first time as causative agent of mortality in commercial farm in West Java and Central Java, in since 2003. The outbreak was continued to spread to other provinces and all provinces have reported the disease, except Gorontalo and Maluku provinces (Komnas FBPI, 2008). Unfortunately in 2011, AI outbreak has been reported in Gorontalo (http::/ / ditjennak.deptan.co.id), where previously known as free AI cases and the infection still existing sporadically throughout Indonesia.So far it has been known

\section{*Corresponding author:}

Michael Haryadi Wibowo

Department of Microbiology, Faculty of Veterinary Medicine, Universitas Gadjah Mada, Jl. Fauna, Karangmalang, Yogyakarta 55281.

Email: bowomikro@yahoo.com that the infection is caused by H5N1 subtype (Asmara et al., 2005; Dharmayanti et al., 2005-a; Mahardika 2005; Wibowo et al., 2006; Wibowo et al., 2007). The virus is highly pathogenic for poultry and it causes high economic loss impact, owing to high mortality of birds, birds eradication cost, and poultry product exportimport restriction.

Avian influenza virus is a member of the family Orthomyxoviridae, genus Influenza A virus. Viral genome is segmented and consist of single stranded-RNA, negative sense, and has eight segments gene which responsible for internal and surface protein. Surface protein consists of Haemagglutinin $(\mathrm{H} / \mathrm{HA})$, neuraminidase (N/NA) and matrix (M2). Internal proteins are nucleoprotein (NP), polymerase complex (PB1, PB2, and PA), matrix (M1), and nonstructural protein (NS1 and NS2). Influenza A virus is classified into type $A, B$, and $C$ based on matrix or 
nucleoprotein antigenic character. Influenza virus $A$ are further divided into subtype based on antigenicity character of HA and NA proteins (Cox and Kawaoka, 1998). To date, $16 \mathrm{HA}$ and 9 NA subtype have been recognized (Fourchier et al., 2005).

Haemagglutinin (HA) is glycoprotein projection viral and formed as a homotrimer comprising three identical subunits that contain two polypeptide chains called HA-1 and HA-2. This polypeptide is linked in each subunit by single disulphide bond (McCauley and Mahy, 1983). It is encoded by the fourth largest RNA segment and widely distributed on the surface of virion reaching approximately $80 \%$. This Haemagglutinin is a principal antigen which plays vital role for infection. In the process of infection, HA will undergo post translational cleavage by certain protease enzyme into HA1 and HA2 sub-unit(Cox and Kawaoka, 1998). The HA1 is receptor binding protein as the major target of immune responses, whereas HA2 is an anchor protein of the envelope, mediating fusion of the envelope to the cellular endosomal membrane (Suzuki and Nei, 2002).

Recent studies have revealed an understanding of pathogenicity at molecular level. It has been shown to be associated with the presence of multiple basic amino acids at the cleavage site of the HA glycoprotein (Senne et al., 1996). Cleavage site (CS) region of HPAI viruses differ from those of a virulent influenza A viruses by the virtue of possessing multiple basic amino acid of the carboxyl terminus of HA1, especially arginine and lysine. This feature permits cellular protease such as furine-like endoprotease to recognize multiple basic amino acids, which in turn cleaves the HA and renders the virus infection. Such a kind of condition permits the virus to spread in a variety of organs, leading to systemic infection. Whereas most a virulent strains have a single arginine or monobasic cleavage site that will be cleaved only by trypsin secreted from cells in the respiratory and intestinal tract, so the virus only produced localized infection (Harimoto and Kawaoka, 2001; Ito et al., 2001).

Field examination focusing on clinical signs of infected poultry in Indonesia indicated some variations in macroscopic lesions. Formerly, the infected bird exhibited characteristic symptoms, e.g.: high mortality rate, hemorrhages on the shank and hock joint, congestion and cyanosis on the comb and wattle, which can be followed by edema gelatinous. The development of clinical signs, started in 2005, today in some cases of AI infection could not always indicate specific symptoms although the circulating virus remain highly pathogenic $\mathrm{H} 5 \mathrm{~N} 1$. So far, there has not been any evidence that another H5N1 subtype and pathotype infection occurs in poultry. This research was aimed to characterize the fragment of HA gene of avian influenza virus responsible for pathogenicity marker of AIV, isolated from various poultry since 2003 to 2013 would be elucidated by amplifying and sequencing of this regions.

\section{Materials and Methods}

The study was retrospective study which was designed to characterize the cleavage site and fusion site of HA gene fragment of AIV isolated from 2003 to 2013. Isolation, identification, and molecular characterization was done in the Laboratory of Microbiology, Gadjah Mada University and Biotechnology Center, Disease Investigation Center, Lampung. Sequencing was performed in the laboratory which equipped with sequencing facilities in PT. Charoen Pockphan Indonesia, Jakarta and Centre for Veterinary Biologics (Pusat Veterinaria Pharma), Surabaya.

\section{Materials}

Field poultry samples suspected to AIV infection from several outbreak places in Java Island and Lampung province from 2003 to 2013have been collected. Those samples were collected from AI cases with and without specific symptoms for AIV infection. Some samples stocked as organ samples need for further process to viral isolation and propagation. 


\section{Methods \\ Isolation and Propagation}

Lung samples collected from suspected poultry have been prepared for further processed and then inoculated into allantoic sac of SPF embryonated chicken egg of 11 days old. Cropped viral in allantoic fluid was tested on its ability to agglutinate chicken red blood cell or haemagglutination (HA) test. HA positive indicated the growth of both AIV and NDV. Positive HA test isolate then continued to haemagglutination inhibition (HI) test using specific antibody to AIV H5N1 subtype to confirm the presence of AIV. Isolation and identification were based on the procedures of World Health Organization on avian influenza diagnostic and surveillance (WHO, 2002). Infected allantoic fluid samples were stored for further processed of molecular characterization.

\section{Viral Sub-typing Identification \\ RNA extraction.}

Viral RNA was extracted from allantoic fluid using RNA extraction kit Invitrogen Pure Link ${ }^{\mathrm{TM}}$ Micro to Midi 50xRxn Total RNA Purification System (Catalog number: 12183018) according to the manufacturer's protocol. To purify total RNA from $0.2 \mathrm{ml}$ allantoic fluid, in a $1.5 \mathrm{ml}$ RNAse-free micro centrifuge tube was added $0.2 \mathrm{ml}$ of RNA lyses solution contain 1\% (v/v) 2-mercaptoethanol. The mixture was vortexed thoroughly to disrupt and lyse blood cells, and centrifuged at $12,000 x g$ for 2 minutes at room temperature. Supernatant was transferred to clean $1.5 \mathrm{ml}$ RNA-se free micro centrifuge tube and $200 \mu \mathrm{l}$ of $100 \%$ ethanol was added. Any precipitate was dispersed by vortexing or pipetting up and down several times. The sample was transferred to the RNA spin cartridge, centrifuged at $12,000 \times \mathrm{xg}$ for 15 seconds at room temperature. The flow-through was discarded and $700 \mu \mathrm{l}$ of Wash Buffer I to the spin cartridge was added and centrifuged at $12,000 \times$ f for 15 seconds at room temperature. The spin cartridge was placed into a clean RNA Wash Tube and $500 \mu$ l of Wash Buffer II with ethanol was added to the spin cartridge then centrifuged at $12,000 \times \mathrm{xg}$ for 15 seconds at room temperature. The flow-through was discarded. This step was repeated once. The spin cartridge was centrifuged at 12,000 x g for 1 minute at room temperature to dry the membrane, and the cartridge was moved into an RNA Recovery Tube. Sixty $\mu$ l of RNAse-free water was added to elute the RNA and incubated for 1 minute at room temperature then centrifuged for 2 minutes at $12,000 x g$ at room temperature. This step was repeated, and then the cartridge was discarded and elutes was stored at $-4^{\circ} \mathrm{C}$.

\section{Thermocycling}

One step Reverse transcriptase-PCR (RT-PCR) was carried out in GeneAmp ${ }^{\circledR}$ PCR System 2400 machine and performed using Invitrogen SuperScript ${ }^{\mathrm{TM}}$ III One-Step RT-PCR System. Primers designed for this research were $\mathrm{H} 5$ and $\mathrm{N} 1$ and listed in the Table 1.

Primers 1 and 2 used to amplify fragment HA and NA gene of AIV isolated from 2003 to 2008, meanwhile primers 3 and 2 used to amplify fragmen HA and NA gene of AIV obtained from 2009 to 2013. However, primer 3 from AAHL. (2010) also be used to amplify some AI viruses isolated

Table 1. Primer used in this study.

\begin{tabular}{|c|c|c|c|c|}
\hline Number & Primer Name & Sequence $5^{\prime}$ to $3^{\prime}$ & Product size & Position and Reference \\
\hline 1 & $\begin{array}{l}\mathrm{H} 5-\mathrm{F} \\
\mathrm{H} 5-\mathrm{R}\end{array}$ & $\begin{array}{l}5^{\prime} \text {-ggagactcagcaatcccatgaaaag-3' } \\
5^{\prime} \text {-ccataccaaccgtctaccattcc-3' }\end{array}$ & $246 \mathrm{bp}$ & $\begin{array}{l}775-1021 \\
\text { Ito et al., } 2001\end{array}$ \\
\hline 2 & $\begin{array}{l}\text { NA1-F } \\
\text { NA1-R }\end{array}$ & $\begin{array}{l}5^{\prime} \text {-gtt tga gtc tgt tgc ttg gtc- } 3^{\prime} \\
5^{\prime} \text {-tga tag tgt ctg tta tta tgc c-3' }\end{array}$ & $131 \mathrm{bp}$ & $\begin{array}{l}458-589 \\
\text { Payungporn et al., } 2004 .\end{array}$ \\
\hline 3 & $\begin{array}{l}\text { HA.30-F } \\
\text { HA.30-R }\end{array}$ & $\begin{array}{l}5^{\prime} \text {-cca tga gaa cca gaa gtt cag ca- } 3^{\prime} \\
5^{\prime} \text {-gga tgg cag gga atg gta gat g- } 3^{\prime}\end{array}$ & $705 \mathrm{bp}$ & $\begin{array}{l}\text { 657-1361 } \\
\text { AAHL, } 2010\end{array}$ \\
\hline
\end{tabular}


in 2008. Cycling condition for H5, HA.30, and NA1 were initially done with a reverse transcription step at $50^{\circ} \mathrm{C}$ for 30 minutes and a hot start step at $94^{\circ} \mathrm{C}$ for 5 minutes. For $\mathrm{H} 5$ amplification was performed as follow : denaturation $\left(94^{\circ} \mathrm{C}\right.$ for 30 seconds), annealing $\left(50^{\circ} \mathrm{C}\right.$ for 1 minute) and extension $\left(68^{\circ} \mathrm{C}\right.$ for 45 seconds), and ended by final extension at $68^{\circ} \mathrm{C}$ for 5 minutes. For HA.30 amplification was performed as follow: denaturation $\left(94^{\circ} \mathrm{C}\right.$ for 30 seconds), annealing $\left(50^{\circ} \mathrm{C}\right.$ for 40 second), extension $\left(68^{\circ} \mathrm{C}\right.$ for 40 seconds), and ended by final extension at $68^{\circ} \mathrm{C}$ for 5 minutes. Amplification of NA gene using NA-1 primer was done as follow: denaturation $\left(95^{\circ} \mathrm{C}\right.$ for 30 seconds), annealing $\left(55^{\circ} \mathrm{C}\right.$ for 45 seconds), extension $\left(72{ }^{\circ} \mathrm{C}\right.$ for 60 seconds), and ended by final extension at $72^{\circ} \mathrm{C}$ for 5 minutes. Total cycles performed in PCR session was 40 times.

\section{Electrophoresis of PCR Product}

PCR products were electrophoresis in $1.5 \%$ Agarose gel in $1 \times$ TBE. Electrophoresis tank used MSMIDIDUO, Cleaver Scientific Ltd. Gel was running at $100 \mathrm{~V}$ for 40 minutes, and read under UV transilluminator at 302 nm wave length to determine the size of PCR product fragment.

\section{Sequencing and sequence analysis}

PCR products of HA gene were sent to laboratory which has sequencing facilities, and prior to be sequenced the PCR product should be purified. Primers used to sequence the targeted HA fragment genes were the same with previous primers to amplify. Sequences yielded were analyzed by MEGA version 5.0, include sequence editing, multiple alignment, and deductive amino acid prediction (Tamura et al., 2007).

\section{Result and Discussion \\ Molecular identification}

Propagation and identification of all samples showed positive for AIV H5N1 and negative for Newcastle disease virus (NDV), which were characterized using serum anti specific for both AIV and NDV. Molecular identification in this study was based on the amplification of $\mathrm{H} 5$ fragment gene at position 775 to 1021 with product size at $246 \mathrm{bp}$ (Ito et al., 2001) particularly for AIV isolated from 2003 to 2008 (Figure 1), meanwhile AIV obtained from 2009 to 2013 used the primer which was targeted of HA gene at position 657 to 1361 with product size at $705 \mathrm{bp}$ (AAHL., 2010) (Figure 2). Molecular identification of $\mathrm{H} 5$ gene according to Wibowo et al. (2007) reported that the same primer designed has been used successfully to characterize fragment HA gene of some virus isolated from 2003 to 2005. Molecular identification has been conducted by Asmara et al. (2005) for AIV

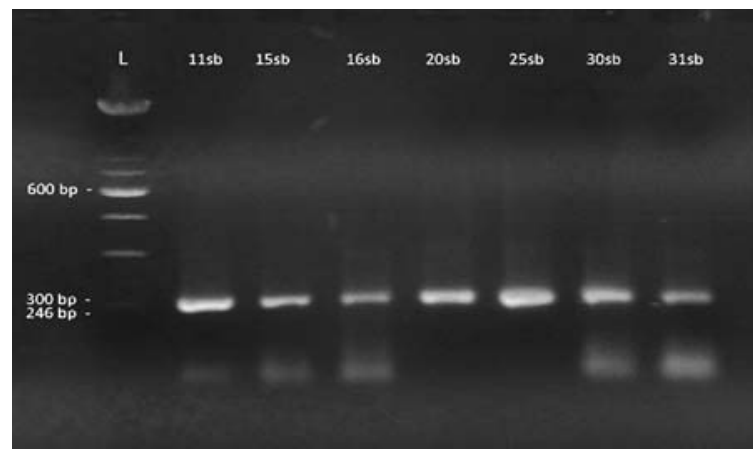

Figure 1. Electrophoresis prolife of HA-5 gene fragment indicated DNA band of $246 \mathrm{bp}$ product size. All samples in lane 11sb, $15 \mathrm{sb}, 16 \mathrm{sb}, 20 \mathrm{sb}, 25 \mathrm{sb}, 30 \mathrm{sb}$ and $31 \mathrm{sb}$ were positive result.

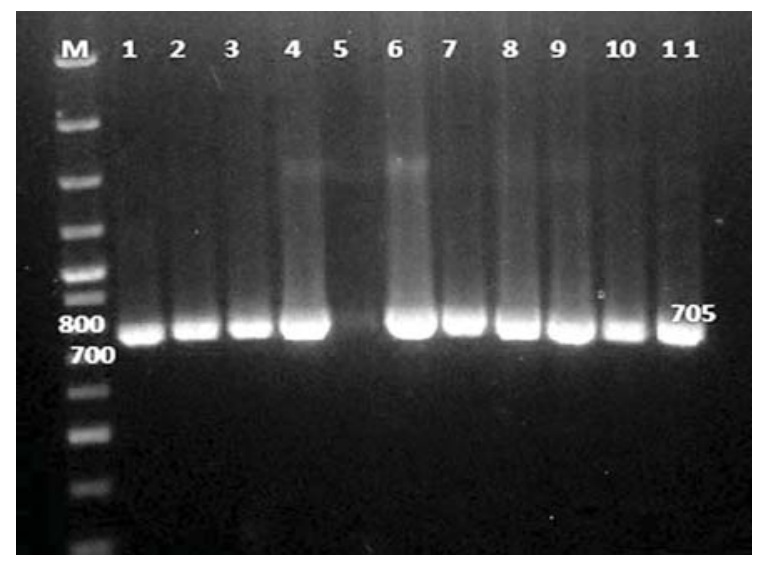

Figure 2. Electrophoresis prolife of HA-5 gene fragment using AAHL primer indicated DNA band of $705 \mathrm{bp}$ product size. Samples in lane 1,2,3,4,6,7,8,9,10, and 11 were positive, but lane 5 was negative. 


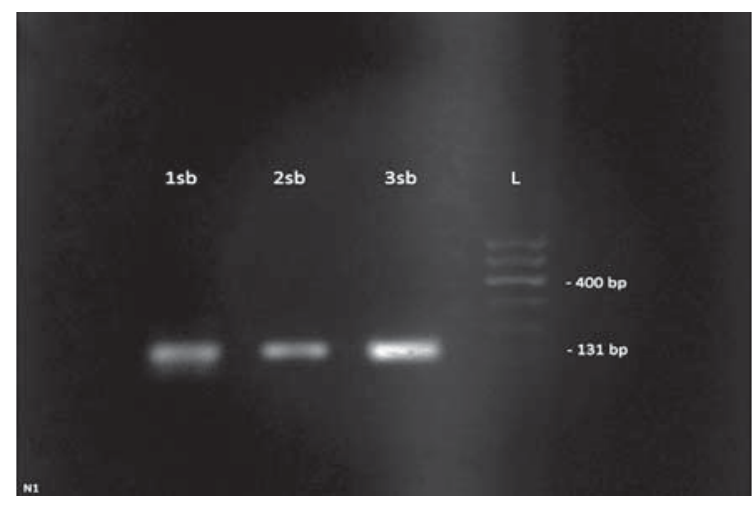

Figure 3: Electrophoresis prolife of NA gene fragment indicated DNA band of 131 bp product size. All samples in lane $1 \mathrm{sb}, 2 \mathrm{sb}$, and $3 \mathrm{sb}$ were positive result.

isolated from various birds sample taken from Java in the early AIV outbreak. He used H5 primer designed by Spackman et al. (2002) to amplify fragment HA gene. The primer was actually designed for AIV American isolates but it could work for Indonesian isolates. The $\mathrm{H} 5$ identification has been reported by Dharmayanti et al. (2005-a and 2005-b) which used primer designed by Lee et al. (2001) with the amplification target at 545 bp. Meanwhile Wibowo et al. (2007), were using WHO primer designed with 600 bp product size. They could identify some AIV isolated from various regions in Indonesia. WHO primer that once suggest by World Health Organization (WHO) also broadly used to VAI detection, particullarly in the early AIV outbreak in Indonesia. Primers designed by Australian Animal Health Laboratory already validated and used in all diseases investigation centre throughout Indonesia.

Amplification of NA-1 gene fragment of AIV isolated from 2003 to 2013 was based on primer which were designed by Payungporn et al. (2004) at position 458 to 589 with product size at $131 \mathrm{bp}$ (Figure 3). The N1 sub typing using the same primer designed has been reported by Mahardika (2005) and Wibowo et al. (2007) particularly to detect some cases of AIV infection in an early outbreak in Indonesia. They successfully performed the amplification by using the primer.

\section{Analysis of cleavage site area.}

Further characterization of AIV at the pathogenicity marker, was based on amplification of HA gene fragment of cleavage site area. It is believed that amino acid configuration at cleavage site region would determine pathotype of AIV. The presence of polybasic amino acids in that region is important as a pathotypic marker of AIV (Bank and Plowright, 2003). Our result of pathogenicity study at molecular level indicated that some AI viruses obtained from West Java, Central Java, Yogyakarta Special Province, East Java, and Lampung Province which were isolated from various species of birds since 2003 to 2013 could be classified into five motives of basic amino acids. Detail of multiple alignment of this study could be found in Table 2. The first motive was -PQRERRRKKR/GLFGAIAGFIE- which could be observed in the early outbreak during the year of 2003 to 2005 . The CS feature was the same with the ancestral virus Goose/ Guandong/1/1996. The second motive s -PQRE-RRKKR/GLFGAIAGFIE- which indicated a deletion of amino acid at upstream -6 and was found in AI viruses isolated in the year 2003, 2004, and 2007. The third motive was -PQRESRRKKR/GLFGAIAGFIE- and could be found in AIV isolated from 2006 to 2011 which were predominantly showed a mutation upstream -6 of arginine into serine. The forth motive was -PQRESRRKRR/ GLFGAIAGFIE- which indicated a mutation at upstream -2 lysine into arginine. The last identified motive was -PQRE-RRRKR/ GLFGAIAGFIE- which showed not only deletion at position upstream -6 but also a mutation at upstream-3 lysine into arginine, which was found in AIV obtained in 2012 and 2013 and isolated form waterfowl.

According toSenne etal., (1996), minimal motive of amino acid concept is B X B R//, which $B$ is basic amino acid; $X$ is a non-basic amino acid and $R$ is arginine that is related to restriction area (sign //). Meanwhile Harimoto and Kawaoka (1994) reported two kinds of structural features which are 
Table 2. Multiple alignment of cleavage site area at position upstream -16 until downstream +14 . Sign / indicated cleavage site position.

\#AF144305.1A/Goose/Guandong/1/1996 \#GQ122385.1| A/Chicken/East-Java/2003 \#GQ122389.1 | A/Quail/Jogja/2004 \#DQ497657.1 | A/Chicken/Jembrana/2004 \#GQ122555.1 | A/Chick/East_Java/2006 \#EU124157.1 | A/Chicken/Papua/2006 \#EU124152.1|A/Chicken/JKT/2006 \#EU124208.1 | A/Chicken/GK/2006 \#GQ122402.1 | A/Chicken/Jatim/2007 \#EU124212.1 | A/Chicken/MGL/2007 \#EU124214.1 |A/Chicken/SMG/2007 \#A/Broiler/Klaten/MHW-CS-9/2003 \#A/Layer/Purwokerto/MHW-CS-12/2003 \#A/Layer/Klaten/MHW-CS-13/2003 \#A/Duck/Jatim/MHW-CS-8/2003 \# A/Layer/Lampung/MHW-CS-14/2004 \#A/Layer/Solo/MHW-CS-6/2004 \#A/Layer/KP-Congot/CS1/2004 \# A/Layer/Jogja/MHW_CS-32/2004 \#A/Quail/Jogja/MHW-CS-2/2005 \#A/Layer/MGL/MHW-CS-4/2005 \#A/Layer/MGL/MHW-CS2-AL2/2005 \# A/MD/MGL/UGM-CS-UA2/2006 \#A/Duck/Jogja-PST/UGM-UA3/2006 \# A/Layer/Jabar/MHW-CS-13/2006 \#A/MD/Muntilan/Pokja-CS-15/2007 \#A/Bird/Muntilan/Pokja-CS-20/2007 \# A/Layer/Solo/MHW-CS-25/2007 \#A/NC/Muntilan/Pokja-CS-AK3/2007 \# A/Quail/Jogja/MHW-CS-30/2007 \#A/Layer/Jatim/MHW-CS-AL1/2007 \#A/NC/GK/MHW-CS-AK2/2007 \#A/NC/BGTP/MHW-CS-AK4/2007 \#A/NC/Jogja/MHW-CS-01/2008 \# A/Layer/Jabar/MHW-CS-02/2008 \#A/NC/Jogja/MHW-CS-03/2008

\#A/Broiler/Semarang/MHW-CS-05/2008

\#A/NC/Jogja/MHW-CS-06/2008

\#A/Ck/Waylaga/BppvIII_08.55/2008

\#A/Ck/Muaraenim/BppvIII_08.48/2008

\#A/Ck/Bandarlampung/BppvIII_09.151/2009

\#A/Ck/Waylaga/BppvIII_09.219/2009

\#A/Ck/Kepahyang/BppvIII_10.692/2010

\#A/Qa/Metro/BppvIII_10.67/2010

\#A/Ck/Bangka/BppvIII_10.420/2010

\#A/Ck/Lampung_Selatan/BppvIII_10.24/2010

\#A/Ck/Rejanglebong/BppvIII_11.337/2011

\#A/Duck/Trimurjo/BppvIII_12.1182/2012

\#A/Muscovy_duck/Muaraenim/BppvIII_13.73/2013

\#A/Muscovy_duck/Pesawaran/BppvIII_13.36/2013

\section{TGLRNTPQRE RRRKKR/GLFG AIAGFIEGGW}

...........

...........

..........

..........

.....S...

.........

..........

..........

.........

.....S....

.....S...

..........

..........

.....S....

.....S...

..........

...........

.....S....

.....S....

..........

..........

.....S....

.....S...

K....S...

.....S....

.....S....

..........

..........

...........

.....S....

.....S...

..........

.....S....

.....S....

..........

.....S....

.....S....

..........

..........

.....S....

.....S....

..........

.....S....

.....S....

..........

.....S....

..........

............

..........<smiles>CC1CC1</smiles>

...... $/ \ldots$

..........

...... /....

...........

S..... /...

S..... ....

....../...

S...../...

S...../....

...........

..........

....../....

-.........

....../....

-...../....

...........

...........

...........

..........

....../....

S...R./....

S.........

S..........

$-. . . . / . . .$.

-..........

S.........

-...../....

S...R./....

S..........

S...R./....

S...R./....

S..........

S..........

S..........

S.........

S..........

S..........

S.........

S.........

...........

S..........

S.........

S..........

S..........

S.........

-..R../...

-..R../....

-..R../....

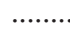

…............

……....

……..........

………

………

...............

………

............

...........

...........

…….....

……....

............

……….

............

...........

............

............

..........

……….

...........

.

............

...........

............

...........

............

………

............

..........

............

.............

………

………

...........

............

............

Note: Bold type indicate investigated AIV isolates 
critical for determining HA cleavability by protease. A series of amino acids in the cleavage site area and the presence or absence of carbohydrate chain in the near vicinity will determine cleavability of HA gene. In order HA to be cleaved, at least six basic amino acids have to be present at the cleavage site if carbohydrate site chain is nearby, otherwise only for basic amino acid is needed. Following in amino acid level conversion, all AIV isolates in this research have the same motive to fulfill the minimal concept of HPAI virus according to Senne et al. (1996); Harimoto and Kawaoka (1994), and still consistent with few kinds of studies that were reported by another researcher.

The feature of -PQRERRRKKR/ GLFGAIAGFIE- at the cleavage site area in our result is the same to the most Indonesian AI viruses in the early of outbreak (Dharmayanti et al., 2005-b; Dharmayanti and Indriani, 2007; and Smith et al., 2006). Compared with that of H5N1 from Indonesia, Thailand, and Vietnam seem to be identical and consistent with -PQRERRRKKR/GLF- but differ from Guandong isolate (A/China/GD01/2006) which lost a basic amino acid (Lys) at position -2 and showed a Gln to Leu substitution at position -8 at cleavage site area (Zhou et al., 2007). One of cleavage site motive in our result is identical with the previous study that 11 isolates avian viruses from Vietnam, including A/Dk/Vietnam/568/05, has arginine deletion (PQRE-RRKKR// $\mathrm{GLF}$ ).It is different from another virus (A/ $\mathrm{Ck} /$ Vietnam/147/04) that has arginine to isoleucine substitution at position -5 from the cleavage site area (Smith et al., 2006). Another motive which could be reported from our study was -PQRESRRKRR/GLFGAIAGFIEThe feature has substitution amino acid at position upstream -2 lysine into arginine and a bit similar with other two viruses from Indonesia (Ck/KP/BBVet-XII-1/04) and $(\mathrm{Ck} / \mathrm{KP} / \mathrm{BBVet}-\mathrm{XII}-2 / 04)$ motive that have been reported by Smith et al., (2006) which indicated lysine deletion at position upstream -2 (PQRERRRK-R/GLF-).
Predominantly cleavage site motive could be found in AIV obtained from the year 2006 to 2011 and isolated from various poultry. The motive was -PQRESRRKKR/ GLFGAIAGFIE- with a mutation a serine at position upstream -6 into arginine. According to Dharmayanti and Darminto (2009), a new motive of basic amino acid area was discovering at AIV isolated from poultry in 2006, in West Java, Indonesia. They reported a mutation on upstream-6 from arginine to serine at cleavage site position within HA gene. The mutation had never been found in previous isolates, before 2006. Our result emphasized that such kind mutation could be found not only in AIV isolated from West Java but also in other regions in Indonesia.

The new motive which could be reported from our study was PQRE-RRRKR/ GLFGAIAGFIE- which showed not only deletion at position upstream -6 but also a mutation at upstream-3 lysine into arginine. The motive could be found in the AIV obtained during 2012 and 2013 and isolated from waterfowl. Our result is differ with the previous report in Indonesia that cleavage site motive of AIV isolated from duck was -PQRERRRKR/GLF-, (Wibawa et al., 2012). The CS feature is also differ to AIV belong to clade 2.3.2 which were reported for the first time in China 2009 (Li et al., 2011), in India (Nagarajan et al., 2012), in Bulgaria and Rumania (Reid et al., 2011).

Most AIV have arginine on terminal carboxyl HA-1 at upstream-1 position, whereas upstream- 9 and -10 is the proximal end that according to another similar study this position always placed by amino acid glutamine at position-9 and proline at position-10 and these position have so far been considered as a conserved region (Dharmayanti et al., 2005-b; Dharmayanti and Indriani, 2007; Dharmayanti and Darminto, 2009; Susanti et al., 2007; Senne et al., 1996; and Zhou et al., 1999). Our study showed the same result with the previous report that those position are conserved, which can be 
observed not only in AIV isolated in the early outbreak but also in current outbreak.

\section{Analysis of fusion site}

According to Cross et al. (2009), fusion peptide was considered as HA fragment adjacent to cleavage site and has 23 amino acid residues at N-terminal of HA2. Fusion peptide influenza A virus, among $16 \mathrm{VAI}$ subtype were considered highly conserved and lies at position downstream +1 to +11 or a half of N-HA2 (Nobusawa et al., 1991; Perdue et al., 2003).Fusion peptide domain also rich with hydrophilic amino acid, such as: tryptophan $(\mathrm{F})$, valine, leucine, isoleucine, and alanine. This domain was characterized by glycine residue with certain interval. However, this feature is not indicate specific motif, but it may related to structural fusion peptide (Steinhauer et al., 1995; Cross et al., 2009). Fusion domain analysis of HA2 fragment of AIV H5N1 subtype at glycine residue, is generally consistent at position $+1,+4$, and +8 . According to both Russand Engelman (2000) and Kleiger et al.(2001) reported that glycine residue which has GXXXG or GXXG sequences are considered to have important role in the helix stability and interaction between helixes.

Amino acid analysis at position downstream +1 to +11 indicated that all AIV isolates showed highly conserved with the motif -/GLFGAIAGFIE- (Table2).Our result confirmed previous report of Dharmayanti et al. (2005-b), Dharmayanti and Indriani (2007), Dharmayanti and Darminto (2009), and Susanti et al. (2007) which reported that this motif is highly conserved at HA gene fragment of AIV isolated in Indonesia. Our result also in accordance with previous report of Nobusawa et al. (1991), Senne et al. (1996), Ito et al. (2001), Perdue et al. (2003), Zhou et al. (1999), Zhou et al. (2007). However, an AIV H5N1 subtype has been reported showed an amino acid mutation at position of +8 of fusion peptide domain of HA2 (Susanti et al., 2007).

Amino acid position at down streams +1 and +2 in this study so far remains glycine and leucine. Both are aliphatic amino acid. This result was supported by Dharmayanti and Darminto (2009), Dharmayanti et al. (2005-b),Dharmayanti and Indriani (2007), Susanti et al. (2007), Ito et al. (2001), Senne et al. (1996), Zhou et al. (1999), and Zhou et al. (2007). According to Steinhauer et al. (1995), that fusion peptide $\mathrm{HA}$ at position +1 glycine may substituted by alanine, but the mutation will lead HA stability decreased due to an increase of fusion $\mathrm{pH}$. However, +1 glycine cannot be substituted by serine, histidine, leucine, isoleucine, and phenylalanine. The mutation will interfere HA folding and fusion process. Further analysis indicated that glycine residue has a role of structural of virus stability.

\section{Conclusion}

Based on the data in our study, all AIV isolated 2003 to 2013 could be identified as H5N1 subtype. Molecular characterization at pathogenicity marker of HA gene, revealed some motives at the cleavage site position, that were:-PQRERRRKKR/GLFGAIAGFIE-, - PQRE-RRKKR/ G L FGA I A GFIE, - PQRESRRKKR/GLFGAIA GFIE, -PQRESRRKRR/GLFGAIAGFIE-, and -PQRE-RRRKR/GLFGAIAGFIE. All the features are classified as highly pathogenic avian influenza virus. Fusigenic domain of all AIV isolated during the period 2003 to 2013 showed conserved amino acid, with the motive is -/GLFGAIAGFIE-.

\section{Acknowledgement}

Part of the data were obtained from research which were supported by SEAMEO BIOTROP Grant, No.: 047.1/PRSP-SP/ III/2008 and Biosecurity Engagement Program, USDA.

\section{References}

AAHL, 2010. In-House Tests for Emergency Disease Diagnosis and Test Protocols under Development: Molecular Characterization. CSIRO Livestock Industries, Australian Animal Health Laboratory, Geelong, Australia. Un- 
Published Material and Restricted Usage.

Asmara W., Wibowo H.W., and Tabbu C.R., 2005. Subtype Identification of Haemagglutinin gene of Avian Influenza Virus on Various Poultry. J. Sains Vet. 23(1): 42-45.

Banks J., and Plowright L., 2003. Additional Glycosylation at the Receptor Binding Site of the Hemagglutinine (HA) for H5 and H7 Viruses Maybe an Adaptation to Poultry Host, But does It Influence Pathogenecity?, Avian Dis. 47 : 942-950.

Cox N.J., and Kawaoka Y., 1998. Orthomyxoviruses: Influenza. in Microbiology and Microbial Infection, (eds) Collier, L., Balows, A., and Sussman, M., Vol. 1: Virology, Oxford University Press, Inc. New York. Pp.: 386-433.

Cross K.J., Langley W.A., Russell,R.J., Skehel, J.J., and Steinhauer, D.A., 2009. Composition and Functions of the Influenza Fusion Peptide. Protein and Peptide Letters, 16: 766-778.

Dharmayanti N.I.L.P., Indriani R., DamayantiR., and Wiyono A., 2005-a. Isolation and Identification of Avian Influenza Outbreak in October 2004March 2005 in Indonesia. J. Biol. Indon. 8 (9): 341-350.

Dharmayanti N.I.L.P., DamayantiR., Indriani R., Wiyono A., and Adjid R.M.A., 2005-b. Molecular Characterization of Indonesian Avian Influenza Virus. JITV 10 (2): 127133.

Dharmayanti N.I.L.P. and Indriani, R. 2007. Patogenisitas Molekuler Virus avian Influenza pada Beberapa Jenis Unggas di Taman Margasatwa Ragunan dan Upaya Eradikasinya. Media Kedokteran Hewan, 22 (2): 78-83.

Dharmayanti N.I.LP., and Darminto. 2009. Mutasi Virus AI di Indonesia: Antigenic drift Protein Hemaglutinin (HA) Virus Influenza H5N1 Tahun 2003-2006. Media Kedokteran Hewan, 25 (1): 68-73.

Fouchier R.A.M., Munster V., Waltensen A., Besterbroer T.M., HerfstS.., Swith D.,
RimnelzwaanG.F., Olsen B. AndOsterhaus A.D.M.E. 2005. Characterization of Novel Influenza A Virus Hemagglutinin subtype (H16) Obtain from Black Headed Gulls. J. Virol 79 (5): 2814-2822.

Harimoto T., and Kawaoka Y., 1994. Reverse Genetics Provides Direct Evidence for a Correlation of Haemagglutinin Cleavability and Virulence of Avian Influenza A Virus. J. Virol. 68 (5): 31203128.

Harimoto T., and Kawaoka Y., 2001. Pandemic Threat Posed by Avian Influenza A Viruses. Clin. Microbiol. Rev. 14: 129-149. http://ditjennak.deptan.co.id. Montly Report of Avian Influenza Outbreak in Poultry in Indonesia. Updated up to June 30, 2013.

Ito T., Goto H., Yamamoto E., Tanaka H., Takeuchi M., Kuwayana M., Kawaoka Y., and Otsuki K., 2001. Generation of Highly Pathogenic Avian Influenza A Virus from Avirulent Field Isolate by Passaging in Chicken. J. Virol. 75 (9): 4439-4443.

Kleiger G., GrotheR., MallickP., and Eisenberg D., 2002. GXXXG and AXXXA: Common alpha Helical Interaction Motif in Proteins, Particularly in Extremophiles. Biochemistry 41: 5990-5997.

Komnas FBPI, 2008. The Timeline Data of Avian Influenza Outbreak in Indonesia, updated in 2008. National Committee for Avian Influenza and Preparedness of Influenza Pandemic. http:// www.komnasfbpi.go.id/situation/ update,html.

Lee M., Chang P., Shien J., Cheng M., and Shieh H. K., 2001. Identification and Subtyping of Avian Influenza Viruses by Reverse Transcription-PCR. J ofVirol. Method. 97:13-22.

Li Y., Liu L., Zhang Y., Duan Z., Tian G., Zeng X., Shi J., Zhang L., and Chen H., 2011. New Avian Influenza Virus (H5N1) in Wild Birds, Qianghai, Cina. Emerg. Infec. Dis. 17 (2): 265- 26

Mahardika G.N.K., 2005. The Dinamic Study of Avian Influenza Virus in Bali, Nusa 
Tenggara Barat and Nusa Tenggara Timur. Research Report. Partnership Research of Faculty of Veterinary Medicine, Udayana University, Bali and Directorat General of Animal Heath, Departement ofAgriculture, Republic of Indonesia. P.:47.

McCauley J. W., and Mahy W. J., 1983. Structure and Function of The influenza Virus Genome. Biochem. J., 211, 281-294.

Nagarajan S., Tosh C., Smith D.K., Peiris J.S.M., Murugkar H.V., Sridevi R., Kumar M., Katare M., Jain R., Syed Z., Behera P., Cheung C.L., Khandia R., Triphati S., Guan Y., and Dubey S.C., 2012. Avian Influenza (H5N1) Virus Clade 2.3.2 in Domestic Poultry in India. PloS ONE 7 (2): e31844. doi:10-1371/journal. pone.0031844.

Nobusawa E., Oayama T., Kato H., Suzuki Y., Tateno Y., and Nakajima K., 1991. Comparation of Complete Amino Acid Sequences and Receptor Binding Properties Among 13 Serotypes of Hemagglutinine of Influenza A Viruses. Virology, 182, 475-485.

PayungpornS., Piraya P., Salin C., Apiradee T., Juthatip K., Kanisak O. V., Alongkorn A., and Yong P., 2004. Single-Step Multiplex Reverse Transcriptase-Polymerase Chain Reaction (RT-PCR) for Influenza A Virus Sub-type H5N1 Detection. Viral Imm., 17 (4), $588-593$.

Perdue M., Crawford J., Garcia M., Latimer J., and Swayne D., 2003. Occurrence and Possible Mechanisms of CleavageSite Insertions in the Avian Influenza Hemagglutinin Gene. Avian Dis., 47, 182-193.

Russ W.P., and Engelman D.M., 2000. The GXXXG Motif: A Framework for Transmembrane Helix-Helix Association. J. Mol. Biol., 296, 911-919.

Senne D., A., Panigray B., Kawaoka Y., Pearson J., E., Sus J., Lipkind M., Kida H., and Webster G.,H., 1996. Survey of the Haemagglutinin Cleavage Site Sequence of $\mathrm{H} 5$ and $\mathrm{H} 7$ Avian Influenza
Viruses: Amino Acid Sequence at The HA cleavage Site as a Marker of Pathogenicity Potential. Avian Dis., 40, 425- 437.

Spackman, E., Senne, D. A., Myers, T. J., Bulaga, L. L., Garber, L. P., Perdue, M. L., Lohman, K., DAum, L. T., and Suarez, D.L., 2002. Development of a Real Time Reverse Transcriptase PCR Assay for Type A Influenza Virus and the Avian H5 and H7 Hemagglutinin Subtypes. J of Clin. Micribiol., 40 (9), 3256-3260.

Steinhauer D.A., Wharton S.A., Skehel J.J., and Weley D.C., 1995. Studies of the Membrane Fusion Activities of Fusion Peptide Mutants of Influenza Virus Hemagglutinin. J. of Virol., 69 (11), 66436651.

Smith G. D. J., Naipospos T.S.P, Nguyen T. D., de Jong M.D., Vijaykrishna D., Usman, T.B., Hassan S.S., Nguyen T.P., Dao T.P., Bui N.A., Leung Y.H.C., Cheung C.L., Reyner J.M., Zhang J.X., Zhang L.J., Poon L.L.M., Li K.S., Nguyen V.C., Hien T.T., Farrar J., Webster R.G., Chen, H., Peiris J.S.M., and Guan Y., 2006. Evolution and Adaptation of H5N1 Influenza Virus in Avian and Human Host in Indonesia and Vietnam. Virology. www.elsevier.com/ locate/yviro.

Susanti R., Soejoedono, R.D., Mahardika, I.G.N.K., Wibawan, I.W.T., and Suhartono. M.T., 2007. The Potency of Waterfowl as Reservoar of Highly Avian Influenza Virus H5N1 Subtype. Jurnal Ilmu Ternak dan Veteriner, 12 (2), 160-166.

Suzuki Y. and Nei M., 2002. Origin and Evolution of Influenza Virus Hemagglutinin Genes. Mol. Biol. Pharm. Bull., 28 (3), 399-408.

Tamura K., Dudley, J., Nei M., and Kumar S., 2007. MEGA 4: Molecular Evolutionary Genetics Analysis (MEGA) Software Version 4.0. Molecular Biology and Evolution 10. 1093/molbev/msm092.

WHO., 2002. Laboratory Procedures, in World Health Organization on Avian Influenza Diagnosis and Surveillance. WHO Global Influenza Programme 
WHO/CDC/CSR/2002.5 Rev.1. Pp.: 15- 39.

Wibawa H., Prijono, W.B., Dharmayanti N.L.P.I., Irianingsih S.H., Wiswati Y., Rohmah A., Andesyha E., Romlah, Daulay R.S.D., Safitria K., 2012. Outbreak Investigation of Duck in Central Java, Yogyakarta Special Province, and East Java: A New Clade of Avian Influenza Virus H5N1 Subtype in Indonesia. Buletin Laboratorium Veteriner, 12 (4), 2-9.

Wibowo H.W., Asmara W., dan Tabbu C.R., 2006. Isolation and Serological Identification of Avian Influenza Virus from Poultry Sample Obtained from JogjakartaSpecialTerritory and Central Java. J. Sain Vet., 24(1), 77- 83.

Wibowo H.W., Untari T., Susetya H., Wahyuni, Asmara W., dan Tabbu C.R., 2007. Molecular Identification of Avian Influenza Virus both With and Without Specific Symptoms to Avian Influenza Disease.J. Vet., 8 (3), 103-110.

Zhou N.N., Shortridge K.F., Claas E. J., Krauss S.L., Webster R.G., 1999. Rapid Evolution of H5N1 Influenza Viruses in Chicken in Hongkong. J. Virol., 73, 3366 - 3374.

Zhou J.J., Fu J., Fang D.J., Yan H.J., Tian J., Zhou M., Tao J.P., Liang Y., and Jiang L.F., 2007. Molecular Characterization of the Surface Glycoprotein Genes of an H5N1 Influenza Virus Isolated from Human in Guandong, China. Arch Virol., 152, 1515-1521. 